\title{
Localization of the peripheral-type benzodiazepine binding site to mitochondria of human glioma cells
}

\author{
James M. Olson, ${ }^{1}$ Wakelin McNeel, ${ }^{2}$ Anne B. Young ${ }^{3}$ and William R. Mancini ${ }^{1}$ \\ ${ }^{1}$ Department of Pharmacology, ${ }^{2}$ Medical School and ${ }^{3}$ Department of Neurology, University of Michigan, \\ Ann Arbor, Michigan 48109, USA
}

Key words: peripheral benzodiazepine receptors, glioma, mitochondria, isoquinoline binding sites

\begin{abstract}
Subcellular fractionation was performed on human U251 glioblastoma cultures. In all subcellular fractions, the binding of the peripheral benzodiazepine ligand, $\left[{ }^{3} \mathrm{H}\right] \mathrm{PK} 11195$, correlated with the specific activity of monoamine oxidase $(r=0.95, p<0.001)$ and succinate dehydrogenase $(r=0.93, p<0.001)$, two mitochondrial enzymes. The specific activity of plasma membrane and nuclear markers correlated poorly with the presence of PK 11195 binding sites. These data support the mitochondrion as the primary location of peripheral-type benzodiazepine binding sites (PBBS) in human glioma cells.

Mitochondria-rich preparations were then assayed for $\left[{ }^{3} \mathrm{H}\right] \mathrm{Ro5}-4964$ binding. Six nM $\left[{ }^{3} \mathrm{H}\right] \mathrm{Ro5}-4964$ failed to specifically bind to human U251 mitochondria, but bound vigorously to mitochondria from rat C6 glioma. These data indicate that the low affinity of Ro5-4864 for PBBS in human glioma cells compared to those in rat is due to interspecies receptor variation rather than impaired drug transport into human cells.
\end{abstract}

Braestrup and Squires first demonstrated two distinct classes of benzodiazepine binding sites in rats $[1,2]$. The binding sites were named the central benzodiazepine receptor (CBR) and the peripheral benzodiazepine binding site (PBBS) because of their predominance in the brain and non-CNS tissue respectively.

Although there are relatively few neuronal or glial PBBS, the receptor is abundant in glioma cells [3-7]. The high density of PBBS in tumors compared to normal brain parenchyma serves as the basis for positron emission tomographic (PET) imaging of human gliomas using the PBBS ligand, $\left[{ }^{11}\right.$ C]PK 11195 [8]. Development of improved PET ligands and ligands suitable for single photon emission computed tomography (SPECT) or radiotherapy requires an understanding of whether or not ligands must pass through tumor cell plasma membrane in order to bind to PBBS.
Defining the subcellular location of PBBS is also an essential step toward understanding the role of PBBS in cancer cells. In early studies, micromolar concentrations of PBBS ligands were shown to induce differentiation of Friend erythroleukemia cells [9], promote melanogenesis in B16 melanoma cells [10] and inhibit proliferation of mouse thymoma cells [11]. Because the concentration of ligand required to affect cell proliferation correlated poorly with binding affinitiy, the role of PBBS in modulating tumor cell growth was subsequently questioned [12]. Recent studies have demonstrated that PBBS ligands influence tumor cells at concentrations which are consistent with receptor mediated actions. Ikezaki and Black reported that nanomolar concentrations of PK 11195 induced a modest increase in C6 rat glioma cell growth rate when the cells were grown in serum-free medium [13]. In $\mathrm{Nb}$ node lymphoma cells, nanomolar concentra- 
tions of PK 11195 and Ro5-4864 potentiate prolactin-stimulated proliferation but had no effect in the absence of prolactin [14]. PK 11195 and Ro5-4864 $\left(10^{-14}\right.$ to $\left.10^{-6} \mathrm{M}\right)$ also inhibit oxygen consumption of mouse C1300 neuroblastoma cells [15].

The influence of PBBS ligands on neuroblastoma oxygen consumption supports the hypothesis that PBBS modulate mitochondrial respiration. PBBS ligands have been shown to influence mitochondrial respiration in rat kidney [16] and PBBS have been localized to mitochondria in rat kidney [17] and rat adrenal [18]. Binding sites with nearly identical drug binding parameters however, have been localized to human erythrocyte membrane preparations [19] which lack mitochondria and nuclei [20]. A nuclear location for PBBS has also been proposed, but lack of marker enzyme correlation in these studies makes it difficult to assess whether contaminants were responsible for PBBS ligand binding in the nuclear fraction $[5,21,22]$.

The current study was developed because the location of PBBS in human glioma cells cannot be extrapolated from relatively few, conflicting reports of subcellular fractionation studies in nonneoplastic rat tissues. In addition, Ro5-4864 binding was evaluated in mitochondria-rich preparations from human and rat glioma cultures. The purpose of this experiment was to determine whether the previously reported interspecies difference in PBBS affinity for Ro5-4864 and related compounds is due to receptor differences versus impaired transport of PBBS ligands into human cells [23].

\section{Materials and methods}

\section{Drugs and chemicals}

Unlabeled PK 11195 was a gift from Dr. G. Le Fur, Rhone-Poulenc, Genevilliers, France. Unlabeled Ro5-4864 was a gift of Dr. P. Sorter, HoffmanLaRoche, Nutley, NJ. Tritiated PK 11195 (specific activity $=75.2 \mathrm{Ci} / \mathrm{mmol}$ ) and Ro5-4864 (specific activity $=77.9 \mathrm{Ci} / \mathrm{mmol}$ ) were purchased from $\mathrm{Du}$ Pont-New England Nuclear, Boston, MA. $\left[{ }^{3} \mathrm{H}\right] \mathrm{PK}$ 14105 (specific activity $=81 \mathrm{Ci} / \mathrm{mmol}$ ) was purchased from Research Products International,
Mount Prospect, IL. $\left[{ }^{3} \mathrm{H}\right]$ Thymidine was purchased from Moravek Biochemicals Inc., Brea, CA. $\left[{ }^{14} \mathrm{C}\right]$ Tyramine was purchased from Amersham, Arlington Heights, Illinois. Culture media and fetal bovine serum were purchased from Gibco, Grand Island, NY. All other chemicals were purchased from Sigma, St. Louis, MO.

\section{Cultures and tissues}

Human glioblastoma line U251 was obtained from Dr. Darrel D. Bigner of Duke University. Rat glioma line $\mathrm{C}_{6}$ was purchased from American Type Culture Collection, Rockville, MD. Cultures were grown in minimum essential media supplemented with $10 \%$ fetal bovine serum at $37^{\circ} \mathrm{C}$ in humidified air supplemented with $5 \% \mathrm{CO}_{2}$.

\section{Cell disruption}

All procedures were carried out at $4^{\circ} \mathrm{C}$. Fractionation was performed on cells from eighty plates (10 cm diameter) of confluent $\mathrm{U} 251$ cultures which had been grown for 24-36 hours. Monolayers were washed with $4 \mathrm{ml}$ 'H buffer' ( $5 \mathrm{mM}$ HEPES, $0.21 \mathrm{M}$ $\mathrm{d}$-mannitol, $0.07 \mathrm{M}$ sucrose, $2 \mathrm{mM}$ benzamidine, $2 \mathrm{mM}$ phenyl-methyl-sulfonyl fluoride, and $4 \mathrm{mM}$ $\mathrm{MgCl}_{2}, \mathrm{pH}=7.4$ ). Cells were scraped in $15 \mathrm{mls}$ homogenization buffer (' $\mathrm{H}$ buffer' supplemented with $0.2 \%$ Nonidet $\mathrm{P}-40$ ) then ruptured in a Dounce glass homogenizer using 15 strokes with a Type B pestle. Homogenates were spun at $200 \mathrm{~g}$ for $1 \mathrm{~min}$. The pellet, consisting of cells which were resistant to rupture in homogenization buffer, was rehomogenized in $4 \mathrm{ml}$ hypotonic homogenization buffer (diluted $4 \times$ with distilled water). The homogenates were combined and centrifuged at $200 \mathrm{~g}$ for $1 \mathrm{~min}$. Supernatants were strained through 3 layers of gauze. The resulting slurry was designated as the 'homogenate' referred to throughout this paper.

\section{Fractionation}

Two $\mathrm{ml}$ of homogenate were reserved for marker assays. The remaining homogenate was centrifuged at $600 \mathrm{~g}$ for $20 \mathrm{~min}$. The resulting pellet was designated ' $0.6 \mathrm{~K}$ '. The supernatant was centrifuged at $15,000 \mathrm{~g}$ for $20 \mathrm{~min}$. The pellet was gently ground into a paste using an ice-filled test tube. The 
paste was layered over $3 \mathrm{ml}$ of $1 \mathrm{M}$ sucrose and centrifuged for $3 \mathrm{hrs}$ at $40,000 \mathrm{~g}$. The heavy fraction which passed through the sucrose cushion was designated ' $15 \mathrm{~K} \mathrm{Hv}$ ' and the light membranes which remained on top of the cushion were designated as ' $15 \mathrm{~K} \mathrm{Lt}$ '. The supernatant from the $15,000 \mathrm{~g}$ spin was centrifuged at $100,000 \mathrm{~g}$ for $1 \mathrm{hr}$. The subsequent pellet was designated ' $100 \mathrm{~K}$ ' and the solution which failed to pellet at $100,000 \mathrm{~g}$ was designated as 'Sol'.

\section{Enzyme assay}

Clorgyline-sensitive monoamine oxidase was quantitated using [14C]tyramine as the substrate according to the method of Wurtman and Axelrod [24]. One percent bovine serum albumin was included in the assay mixture to stabilize monoamine oxidase activity.

Spectrophotometric assays were measured in a Perkin-Elmer Lambda 3 Spectrophotometer. Succinate dehydrogenase activity was determined by measuring the absorption of reduced imidazolium nitro-tetrazolium violet (INT), extracted in ethyl acetate, at $490 \mathrm{~nm}$ [25]. Alkaline phosphatase activity was determined by measuring the liberation of p-nitrophenol from p-nitrophenylphosphate at $420 \mathrm{~nm}$ as previously described [26].

\section{DNA and protein assays}

DNA was quantitated fluorimetrically using $370 \mathrm{~nm}$ excitation and $440 \mathrm{~nm}$ emission wavelengths in a Perkin Elmer Fluorimeter. Samples were briefly sonicated before the addition of Hoechst dye (butamamide) [27]. Calf thymus DNA was used for the standard curve in each experiment. Protein concentrations were determined by the Bradford assay (Biorad, Richmond, CA). Bovine serum albumin was used for standards.

\section{Binding assays}

Samples were incubated for $60 \mathrm{~min}$ at $4^{\circ} \mathrm{C}$ with $6 \mathrm{nM}\left[{ }^{3} \mathrm{H}\right] \mathrm{PK} 11195$ or $6 \mathrm{nM}\left[{ }^{3} \mathrm{H}\right] \mathrm{Ro5}-4864$. Assays were terminated by vacuum-assisted filtration through Schleicher and Schuell \#32 glass filters which had been treated for $30 \mathrm{~min}$ in $0.3 \%$ polyethyleneimine [28]. The filters were washed $3 \times$ with $5 \mathrm{ml}$ of $50 \mathrm{mM}$ Tris-Cl, $\mathrm{pH} 7.4$.
Nonspecific binding was determined in the presence of $10 \mu \mathrm{M}$ unlabeled PK 11195 . When dry, filters were placed in $5 \mathrm{ml}$ Bio-Safe II scintillant, and assayed for tritium by liquid scintillation spectroscopy.

\section{Purified nuclei preparation}

Monolayers of U251 cells were pulsed with 0.5 microCuries/ml [ ${ }^{3} \mathrm{H}$ ]thymidine for four hours then chased with media five hours prior to fractionation. PBBS in adjacent wells of U251 cells were covalently labeled with the photoaffinity agent $\left[{ }^{3} \mathrm{H}\right] \mathrm{PK}$ 14105 as described previously [29]. Cells were scraped, homogenized, layered over $3 \mathrm{ml}$ of $2.2 \mathrm{M}$ sucrose [30], and centrifuged at $40,000 \mathrm{~g}$ for 3 hours. Fractions, $250 \mathrm{uL}$ each, were collected from the top of the cushion using a Buchler gradient collector.

\section{Results}

Various groups have suggested that PBBS are localized to mitochondria $[17,18]$, plasma membrane $[19,22]$ or nuclei $[5,21,22]$. The enrichment of markers for these components was compared to the enrichment of $\left[{ }^{3} \mathrm{H}\right] \mathrm{PK} 11195$ binding in each of six subcellular fractions (Fig. 1). The enrichment was calculated by dividing a marker's specific activity in the fraction of interest by the specific activity of the marker in the homogenate fraction. The enrichment of $\left[{ }^{3} \mathrm{H}\right] \mathrm{PK} 11195$ binding correlated best with the enrichment of the mitochondrial markers monoamine oxidase and succinate dehydrogenase.

It was not possible to obtain a single fraction to which PK 11195 binding was unique. The correlation between the specific activity of PK 11195 binding and succinate dehydrogenase activity in all fractions of 3 experiments was near unity $(r=0.95$, $\mathrm{p}<0.001$ ) (Fig. 2). The specific activity of PK 11195 also correlated with the specific activity of monoamine oxidase $(\mathrm{r}=0.93, \mathrm{p}<0.001)$ (Table 1). No correlation was observed between PK 11195 binding and alkaline phosphatase activity (Table 1).

A positive albeit weak correlation was observed between PK 11195 binding and the presence of 


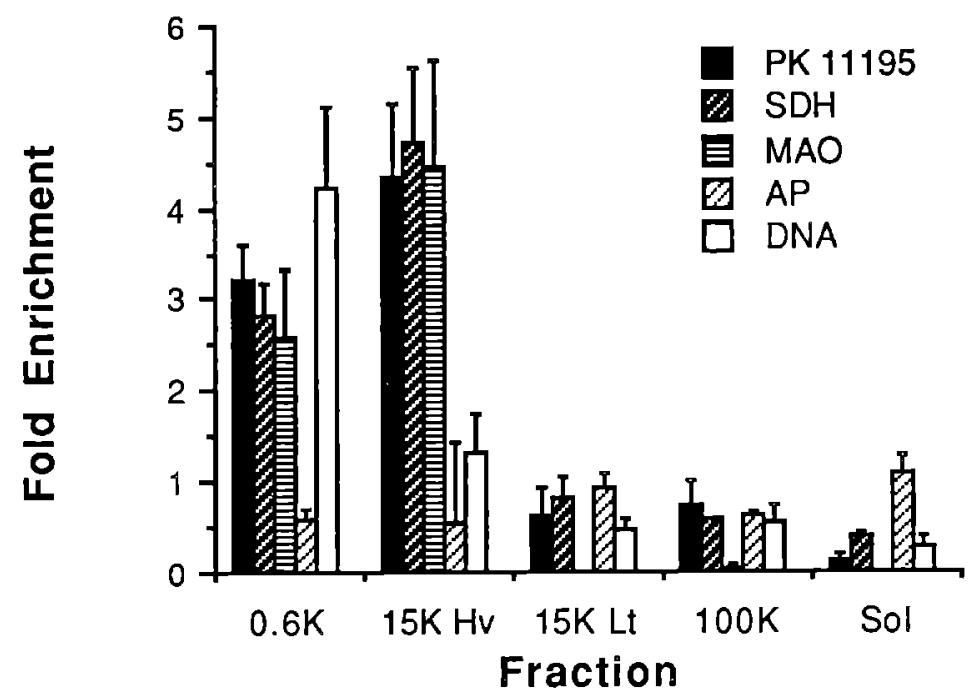

Fig. 1. Enrichment of [ $\left.{ }^{3} \mathrm{H}\right] \mathrm{PK} 11195$ binding and of cellular compartment markers in fractionated human U251 glioblastoma cells. Data are presented as fold enrichment (specific activity in fraction of interest divided by specific activity in homogenate). Columns represent means of four independent experiments, bars $=\mathrm{S}$.E.M. SDH = succinate dehydrogenase, $\mathrm{MAO}=$ monoamine oxidase, $\mathrm{AP}=$ alkaline phosphatase, DNA = deoxyribonucleic acid.

DNA (Table 1). To determine whether glioma cell nuclei contained PBBS, homogenized U251 cells which had been prelabeled with either $\left[{ }^{3} \mathrm{H}\right]$ thymidine or $\left[{ }^{3} \mathrm{H}\right] \mathrm{PK} 14105$, a covalent photoaffinity label for the PBBS, were centrifuged over a $2.2 \mathrm{M}$ sucrose cushion. Greater than $90 \%$ of the $\left[{ }^{3} \mathrm{H}\right] \mathrm{PK}$
14105 was recovered from the top of the cushion while more than $90 \%$ of the $\left[{ }^{3} \mathrm{H}\right]$ thymidine was recovered in the pellet (Fig. 3). To rule out the possibility that $\left[{ }^{3} \mathrm{H}\right] \mathrm{PK} 14105$ recovery represented noncovalently bound drug released from the PBBS during centrifugation, homogenates which had not

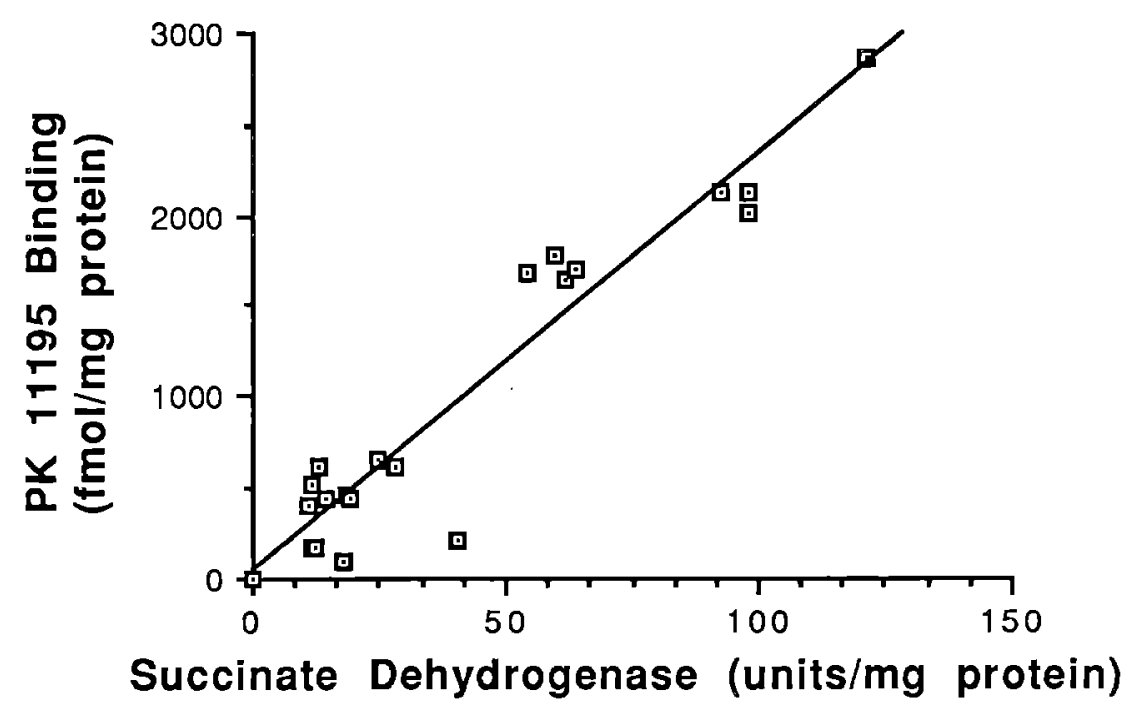

Fig. 2. Correlation between the specific activity of succinate dehydrogenase and PK 11195 binding in fractions of human U251 glioblastoma cells. Data points represent values from homogenate, $0.6 \mathrm{~K}, 15 \mathrm{~K}-\mathrm{Hv}, 15 \mathrm{~K}-\mathrm{Lt}$, and $100 \mathrm{~K}$ fractions of four independent experiments. Linear regression was performed by least squares analysis. 


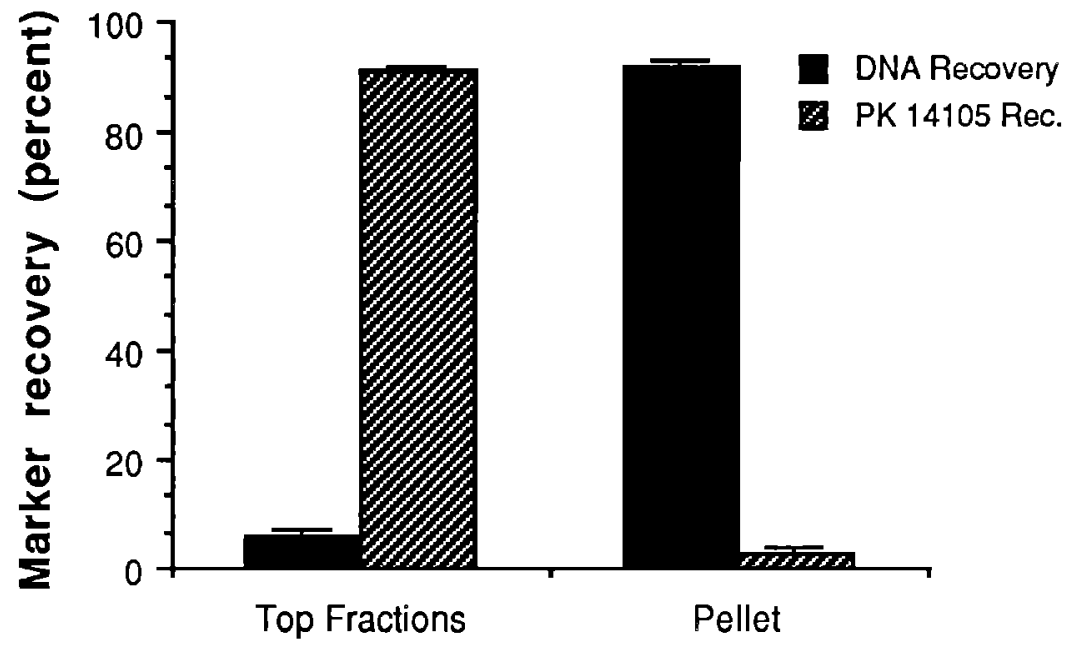

Fig. 3. Recovery of [ $\left.{ }^{3} \mathrm{H}\right] \mathrm{PK}$ 14105-labeled binding sites and $\left[{ }^{3} \mathrm{H}\right]$ thymidine tagged nuclei following separation of the $0.6 \mathrm{~K}$ pellet over 2.2 M sucrose. Cultured cells were labeled with either $\left[{ }^{3} \mathrm{H}\right] \mathrm{PK} 14105$ or $\left[{ }^{3} \mathrm{H}\right]$ thymidine prior to homogenization and centrifugation at $600 \mathrm{~g}$. The $0.6 \mathrm{~K}$ pellet was then centrifuged over a $2.2 \mathrm{M}$ sucrose cushion. Columns represent the mean of three independent experiments, bars $=$ S.E.M.

been labeled with $\left[{ }^{3} \mathrm{H}\right] \mathrm{PK} 14105$ were assayed for $\left[{ }^{3} \mathrm{H}\right] \mathrm{PK} 11195$ binding following centrifugation through the sucrose cushion. In two experiments, greater than $80 \%$ of $\left[{ }^{3} \mathrm{H}\right] \mathrm{PK} 11195$ binding was localized to the topmost fractions while the remaining $\left[{ }^{3} \mathrm{H}\right] \mathrm{PK} 11195$ binding was distributed evenly throughout the remaining fractions. The paucity of $\left[{ }^{3} \mathrm{H}\right] \mathrm{PK} 14105$ or $\left[{ }^{3} \mathrm{H}\right] \mathrm{PK} 11195$ binding in the nuclei-rich pellet indicates that PBBS in the $0.6 \mathrm{~K}$ fraction can be accounted for by non-nuclear organelle contaminants.

$\left[{ }^{3} \mathrm{H}\right] \mathrm{Ro5}-4864$ binding was examined in Hom and $15 \mathrm{~K}-\mathrm{Hv}$ fractions of human U251 glioblastoma cells. In contrast to $\left[{ }^{3} \mathrm{H}\right] \mathrm{PK} 11195$, total binding of
$6 \mathrm{nM}\left[{ }^{3} \mathrm{H}\right] \mathrm{Ro5}-4864$ could not be distinguished from nonspecific binding determined in the presence of $10 \mu \mathrm{M}$ unlabeled PK 11195 (Fig. 4). Control experiments were performed using rat $\mathrm{C} 6$ glioma cells. In these cells, binding of both $\left[{ }^{3} \mathrm{H}\right] \mathrm{PK} 11195$ and $\left[{ }^{3} \mathrm{H}\right]$ Ro5-4864 were largely displaceable by unlabeled PBBS ligands (Fig. 4).

\section{Discussion}

PBBS are more abundant in a number of tumors than in the normal tissue from which the tumors were derived $[3,4]$. The recent demonstration that

Table 1. Correlation between the specific activity of PK 11195 and subcellular markers

\begin{tabular}{lllll}
\hline Marker & Compartment & \multicolumn{2}{l}{ Specific activity } & \\
\cline { 3 - 4 } & & $\mathrm{T}$ & $\mathrm{P}$ \\
\hline Succinate dehydrogenase & Mitochondria & 0.95 & $<0.001$ & 24 \\
Monoamine oxidase & Mitochondria & 0.93 & $<0.001$ & 24 \\
DNA & Nucleus & 0.57 & $<0.025$ & 24 \\
Alkaline phosphatase & Plasma membrane & 0.03 & $<0.05$ & 24 \\
\hline
\end{tabular}

The quantity of [ ${ }^{3} \mathrm{H}$ ]PK 11195 binding was compared to the specific activity of succinate dehydrogenase, monamine oxidase and alkaline phosphatase and to the quantity of DNA in each subcellular fraction of U251 human glioblastoma cells by least squares linear regression analysis. 


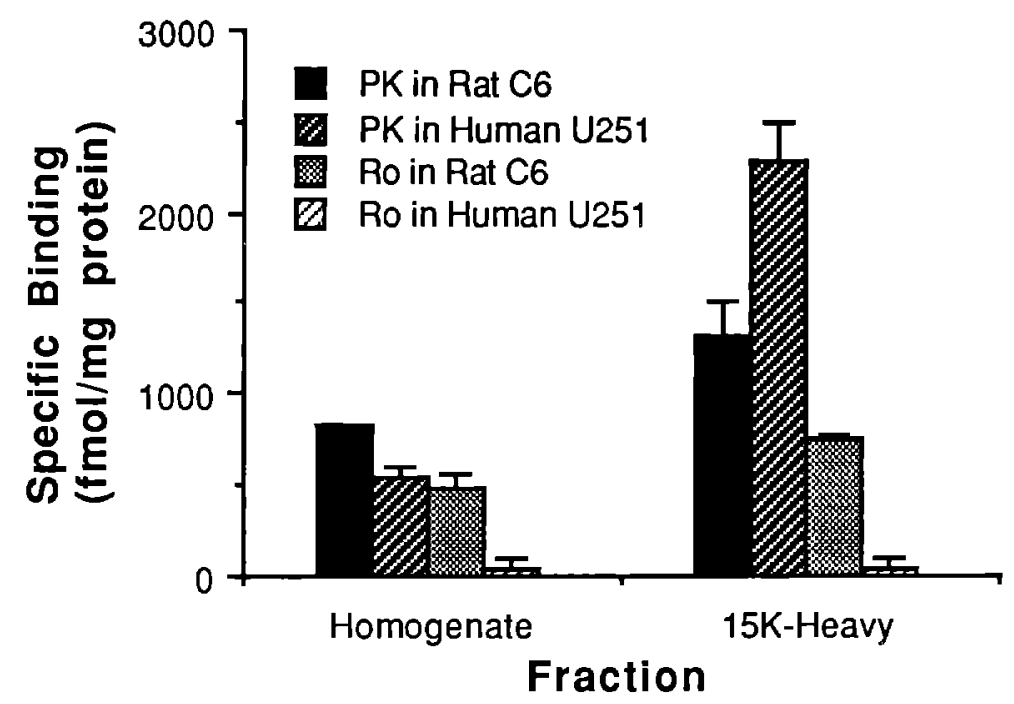

Fig. 4. $\left[{ }^{3} \mathrm{H}\right] \mathrm{PK} 11195$ and $\left[{ }^{3} \mathrm{H}\right] \mathrm{Ro5}-4864$ binding to Hom and $15 \mathrm{~K}-\mathrm{Hv}$ fractions of human $\mathrm{U} 251$ and rat C6 glioma cells. Fractions were incubated in the presence of $6 \mathrm{nM}\left[{ }^{3} \mathrm{H}\right] \mathrm{PK} 11195$ or $\left[{ }^{3} \mathrm{H}\right]$ Ro5-4864 in the presence of $10 \mu \mathrm{M}$ unlabeled PK 11195 (blank) or vehicle (total). Columns represent the mean of 3 independent experiments, bars $=$ S.E.M.

ligands which bind to PBBS are capable of modulating mitochondrial respiration in rat kidney raises the question of whether PBBS modulate tumor cell respiration [16]. Indeed tumor cells have different energy requirements than normal cells $[31,32]$. Furthermore, these requirements must be met by fewer mitochondria per cell than in normal tissues [31]. The first step in determining whether PBBS play a role in tumor cell mitochondrial respiration is to determine whether or not the binding site is present on the organelle.

Although convincing evidence suggests that PBBS are localized to mitochondria in rat adrenal [18] and kidney [17], this finding cannot be generalized to other tissues or species. Human erythrocytes, which lack mitochondria [33], exhibit a PK 11195 binding site which is pharmacologically indistinguishable from rat adrenal PBBS [19].

The results presented in this paper support the hypothesis that PBBS are located primarily on mitochondria in human glioma cells. PK 11195 binding correlated with mitochondrial enzyme recovery while no correlation was observed between PK 11195 binding and the plasma membrane marker alkaline phosphatase. Although there was a modest correlation between DNA content of fractions and the recovery of PK 11195 binding, these two markers could be separated by centrifugation of nuclei through a $2.2 \mathrm{M}$ sucrose cushion. It is impossible to rule out the presence of a small population of non-mitochondrial PBBS due to the difficulty in obtaining contaminant-free fractions of individual organelles.

The localization of PBBS to mitochondria of glioma cells may have implications in the areas of tumor bioenergetics, glioma imaging and the development of new antitumor strategies. The effects of PBBS ligands on tumor cell growth and differentiation might be explained by an action such as the modulation of cellular respiration. Indeed, nanomolar concentrations of PK 11195 and Ro5-4864 suppress oxygen consumption in mouse C 1300 neuroblastoma cells [15]. The relative abundance of high affinity PBBS on mitochondria of tumor cells encourages consideration of PBBS ligands as carriers of radioisotopes or cytotoxic agents to the interior of tumor cells. The fact that drugs must pass through the plasma membrane to reach equilibrium with mitochondrial receptors limits the size and chemical composition of agents that might be linked to PBBS ligands.

This study also demonstrates that mitochondrial PBBS in U251 cells fail to bind $\left[{ }^{3} \mathrm{H}\right] \mathrm{Ro5}-4864$ even in the absence of a plasma membrane barrier or 
cytoplasmic components. This finding supports the hypothesis that interspecies or intertissue differences in the ability of PBBS to bind Ro5-4864 are due to differences at the binding site rather than differential drug uptake, drug metabolism, or the presence of endogenous inhibitors of the Ro5-4864 domain [23].

\section{Acknowledgements}

This work was supported by NPHS Grant NS 15655 and National Research Service Award 5T32 GN 07863.

\section{References}

1. Squires RF, Braestrup C: Benzodiazepine receptors in rat brain. Nature 266: 732-734, 1977

2. Braestrup C, Squires RF: Specific benzodiazepine receptors in rat brain characterized by high-affinity $\left[{ }^{3} \mathrm{H}\right]$ diazepam binding. Proc Natl Acad Sci USA 74: 3805-3809, 1977

3. Starosta-Rubenstein S, Ciliax BJ, Penney JB, McKeever P, Young $\mathrm{AB}$ : Imaging of a glioma using peripheral benzodiazepine receptor ligands. Proc Natl Acad Sci USA 84: 891-895, 1987

4. Syapin PJ, Skolnick P: Characterization of benzodiazepine binding sites in cultured cells of neural origin. J Neurochem 32: 1047-1051, 1979

5. Schoemaker H, Boles RG, Horst WD, Yamamura HI: Specific high-affinity binding sites for $\left[{ }^{3} \mathrm{H}\right] \mathrm{Ro} 5-4864$ in rat brain and kidney. J Pharmacol Exp Ther 225: 61-69, 1983

6. Anholt RRH, Murphy KMM, Mack GE, Snyder SH: Peripheral-type benzodiazepine receptors in the central nervous system: localization to olfactory nerves. J Neurosci 4 : 593-603, 1984

7. Broaddus WC, Bennett JI JP: Peripheral-type benzodiazepine receptors in human glioblastomas: pharmacologic characterization and photoaffinity labeling of ligand recognition site. Brain Res 518: 199-208, 1990

8. Junck L, Olson JMM, Ciliax BJ, Koeppe RA, Watkins GL, Jewett DM, McKeever PE, Wieland DM, Kilbourn MR, Mancini WR, Kuhl DE, Greenberg HS, Young AB: Positron emission tomographic imaging of human gliomas with ligands for the peripheral benzodiazepine binding site. Annals Neurol 26: 752-758, 1989

9. Wang JKT, Morgan JI, Spector S: Differentiation of Friend erythroleukemia cells induced by benzodiazepines. Proc Natl Acad Sci USA 81: 3770-3772, 1984

10. Matthew E, Laskin JD, Zimmerman EA, Weinstein IB, Hsu KC, Engelhardt DL: Benzodiazepines have high-affin- ity binding sites and induce melanogenesis in $\mathrm{B}_{16} / \mathrm{C}_{3}$ melanoma cells. Proc Natl Acad Sci USA 78: 3935-3939, 1981

11. Wang JKT, Morgan JI, Spector S: Benzodiazepines that bind at peripheral sites inhibit cell proliferation. Proc Natl Acad Sci USA 81: 753-756, 1984

12. Gorman AMC, O'Beirne GB, Regan CM, Williams DC: Antiproliferative action of benzodiazepines in cultured brain cells is not mediated through the peripheral-type benzodiazepine acceptor. J Neurochem 53: 849-855, 1989

13. Ikezaki K, Black KL: Stimulation of cell growth and DNA synthesis by peripheral benzodiazepine. Cancer Lett 49 : 115-120, 1990

14. Laird II HE, Gerrish KE, Duerson KC, Putnam CW, Haddock Russell D: Peripheral benzodiazepine binding sites in $\mathrm{Nb} 2$ node lymphoma cells: effects on prolactin-stimulated proliferation and ornithine decarboxylase activity. Eur $\mathrm{J}$ Pharmacol 171: 25-35, 1989

15. Larcher J-C, Vayssiere J-L, Le Marquer FJ, Courdeau LR, Keane PE, Bachy A, Gros F, Croizat BP: Effects of peripheral benzodiazepines upon the $\mathrm{O}_{2}$ consumption of neuroblastoma cells. Eur J Pharmacol 163: 197-202, 1989

16. Hirsch JD, Beyer CF, Malkowitz L, Beer B, Blume AJ: Mitochondrial benzodiazepine receptors mediate inhibition of mitochondrial respiratory control. Mol Pharmacol 34: 157-163, 1989

17. O'Beirne GB, Williams DC: The subcellular location in rat kidney of the peripheral benzodiazepine acceptor. Eur $\mathbf{J}$ Biochem 175: 413-421, 1988

18. Anholt RRH, Pedersen PL, De Sousa EB, Snyder SH: The peripheral-type benzodiazepine receptor: localization to the mitochondrial outer membrane. J Biol Chem 261: 576583,1986

19. Olson JMM, Ciliax BJ, Mancini WR, Young AB: Presence of peripheral-type benzodiazepine binding sites on human erythrocyte membranes. Eur J Pharmacol 152: 47-53, 1988

20. Shuster RC, Rubenstein AJ, Wallace DC: Mitochondrial DNA in anucleate human blood cells. Biochem Biophys Res Com 155: 1360-1365, 1988

21. Marangos PJ, Patel J, Boulenger JP, Clark-Rosenberg R: Characterization of peripheral-type benzodiazepine binding sites in brain using [3H]Ro5-4864. Mol Pharmacol 22: 26-32, 1982

22. Doble A, Benavides J, Odette F, Philippe B, Menager J, Vaucher N, Burgevin M-C, Uzan A, Gueremy C, Le Fur $\mathrm{G}$ : Dihydropyridine and peripheral type benzodiazepine binding sites: subcellular distribution and molecular size determination. Eur J Pharmacol 119: 153-167, 1985

23. Olson JMM, Junck L, Young AB, Penney JB, Mancini WR: Isoquinoline and peripheral-type benzodiazepine binding in gliomas: implications for diagnostic imaging. Cancer Res 48: 5837-5841, 1988

24. Wurtman RJ, Axelrod J: A sensitive and specific assay for the estimation of monoamine oxidase. Biochem Pharmacol 12: $1439-1441,1963$

25. Pennington RJ: Biochemistry of dystrophic muscle: mi- 
tochondrial succinate-tetrazolium reductase and adenosine triphosphatase. Biochem J 80: 649-654, 1961

26. Parry DM, Pedersen PL: Intracellular localization and properties of particulate hexokinase in the Novikoff ascites tumor: Evidence for an outer mitochondrial membrane location. J Biol Chem 258: 10904-10912, 1983

27. Labarca C, Paigen K: A simple, rapid, and sensitive DNA assay procedure. Anal Biochem 102: 344-352, 1980

28. Bruns RF, Lawson-Wendling K, Pugsley TA: A rapid filtration assay for soluble receptors using polyethyleniminetreated filters. AnaI Biochem 132: 74-81, 1982

29. Doble A, Ferris O, Burgevin MC, Menager J, Uzan A, Dubroeucq MC, Renault C, Gueremy C, Le Fur G: Photoaffinity labeling of peripheral-type benzodiazepine-binding sites. Mol Pharmacol 31: 42-49, 1987
30. Chauveau J, Moule $\mathrm{Y}$, Rouiller $\mathrm{CH}$ : Isolation of pure and unaltered liver nuclei morphology and biochemical composition. Exp Cell Research 11: 317-321, 1956

31. Pederson PL: Tumor mitochondria and the bioenergetics of cancer cells. Prog Exp Tumor Res 22: 189-274, 1978

32. Racker E: Bioenergetics and the problem of tumor growth. Amer Scientist 60: 56-63, 1972

33. Heynen MJ, Tricot G, Verwilghen RL: Autophagy of mitochondria in rat bone marrow erythroid cells. Relation to nuclear extrusion. Cell Tissue Res 239: 235-239, 1985

Address for offprints: W.R. Mancini, Department of Pharmacology, 4302 Upjohn Center, Ann Arbor, MI 48109-0504, USA 